\title{
Nairobi informal settlements: COVID-19 knowledge, attitudes, practices and needs-Round 2
}

Population Council

Follow this and additional works at: https://knowledgecommons.popcouncil.org/departments_sbsr-pgy

Part of the Demography, Population, and Ecology Commons, and the International Public Health Commons

How does access to this work benefit you? Let us know!

\section{Recommended Citation}

"Nairobi informal settlements: COVID-19 knowledge, attitudes, practices and needs-Round 2," COVID-19 Research \& Evaluations presentation. Nairobi: Population Council, 2020. 


\section{POPULATION}

\section{COUNCIL}

Ideas. Evidence. Impact.

\section{NAIROBI INFORMAL}

SETTLEMENTS: COVID-19

KNOWLEDGE, ATTITUDES,

PRACTICES \& NEEDS

Population Council Kenya

April 22, 2020 


\section{Overview - Round 2 Data Collection}

- Phone survey conducted on April 13-14

- Kibera, Huruma, Kariobangi, Dandora, Mathare

- 1769 interviews completed ( $88 \%$ of Round 1)

- 37\% male; $63 \%$ female

- Mean age: 36 years

- 18-24: $21 \%$

- 25-34: $20 \%$

- 35-45: $38 \%$

- >45: $21 \%$

- 95\% living in same location as Round 1 


\section{Who is at high risk of severe illness?}

100

90

80

Knowledge on high risk groups remains mixed and declined from Round 1

70 20

70 64

60

50

48

- Round 1

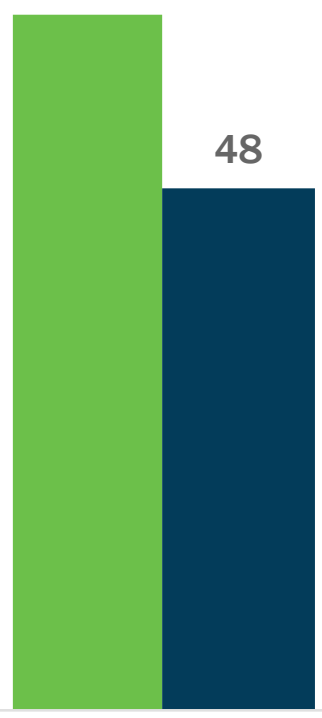

Elderly

Sick/Weak Immune System (including HIV or TB)

19

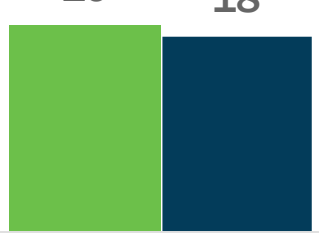

Anybody

Children
- Round 2

44 


\section{What are symptoms of Coronavirus?}

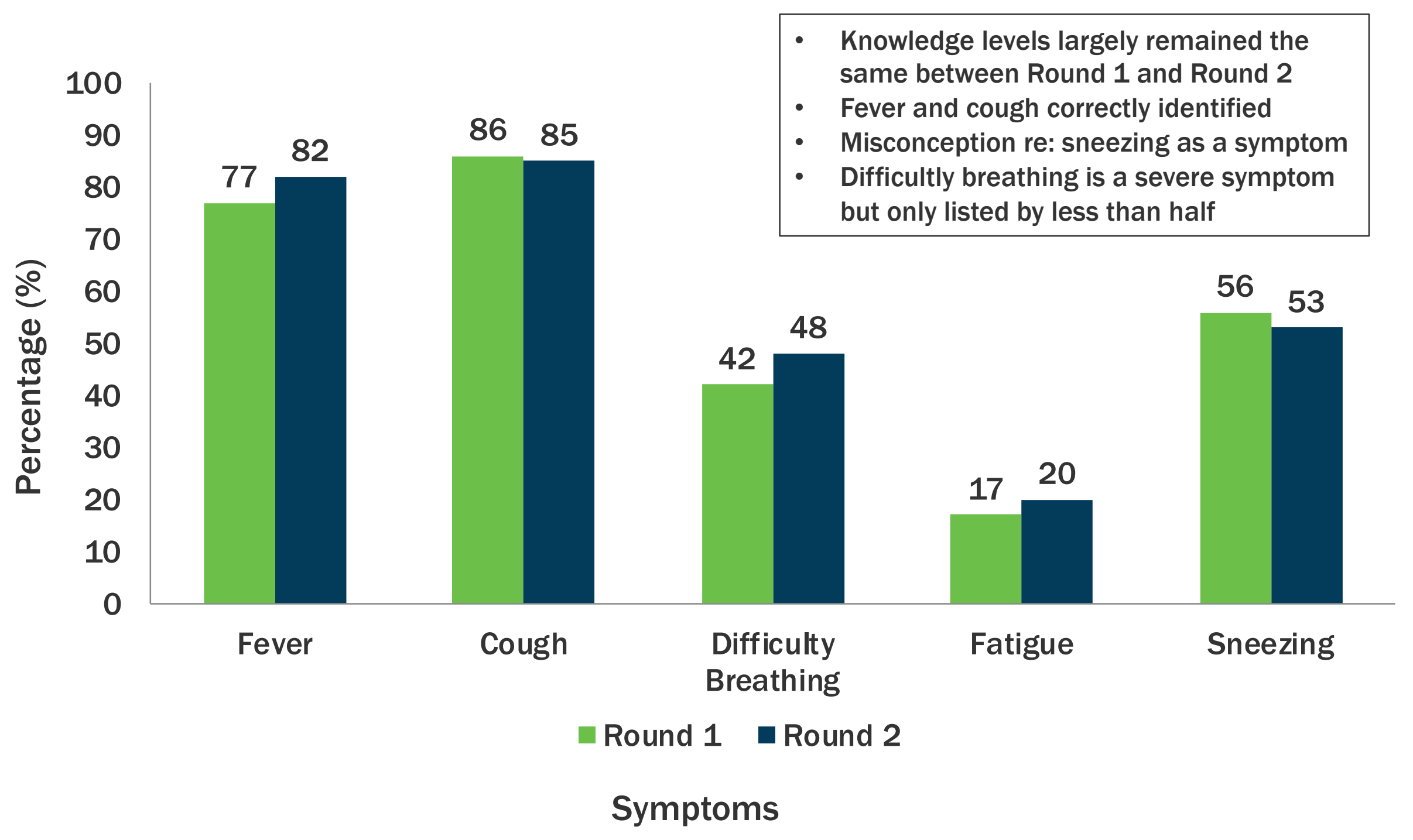




\section{Myths \& Misconceptions on COVID-19}

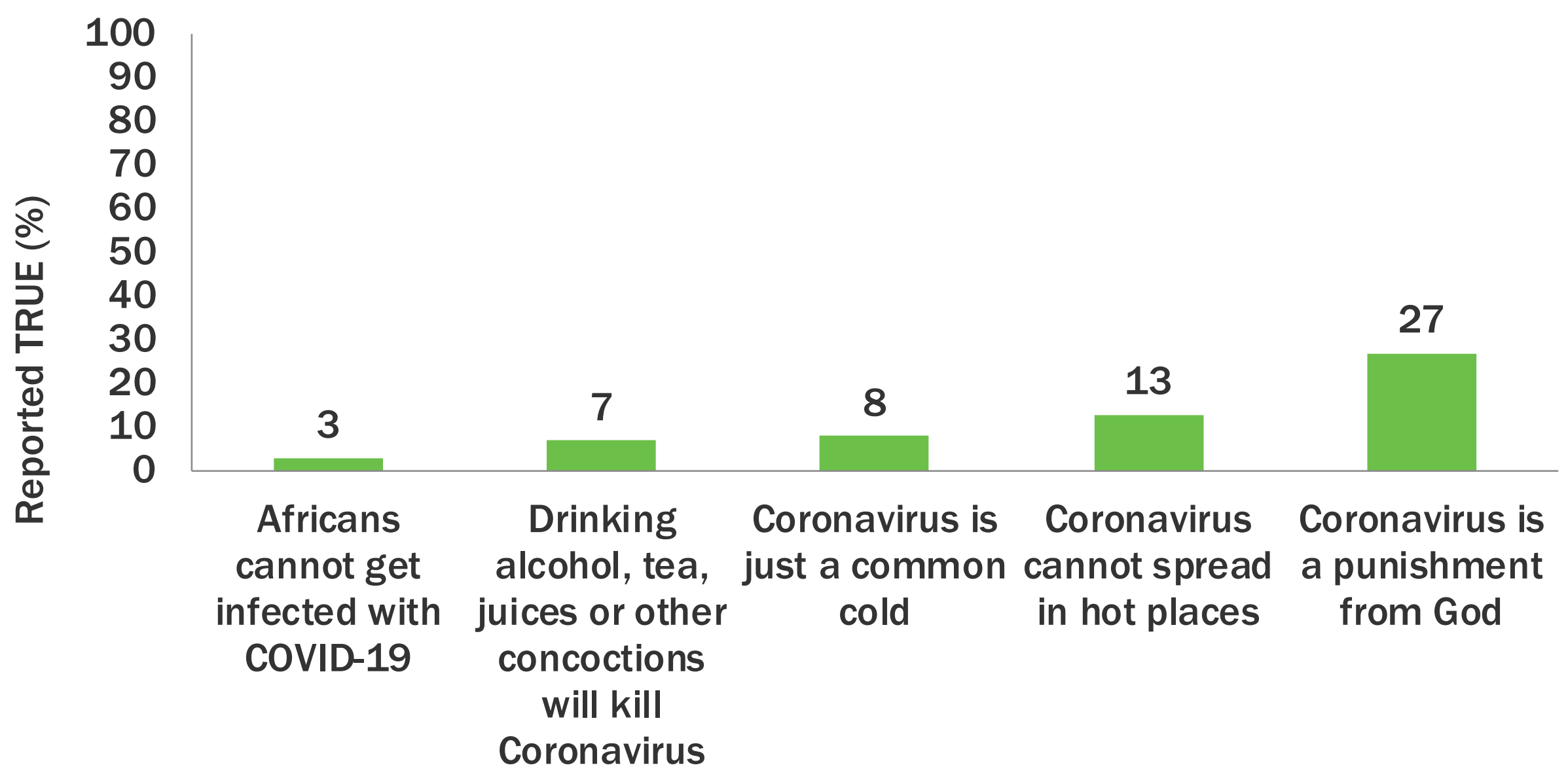




\section{How can infection be prevented?}

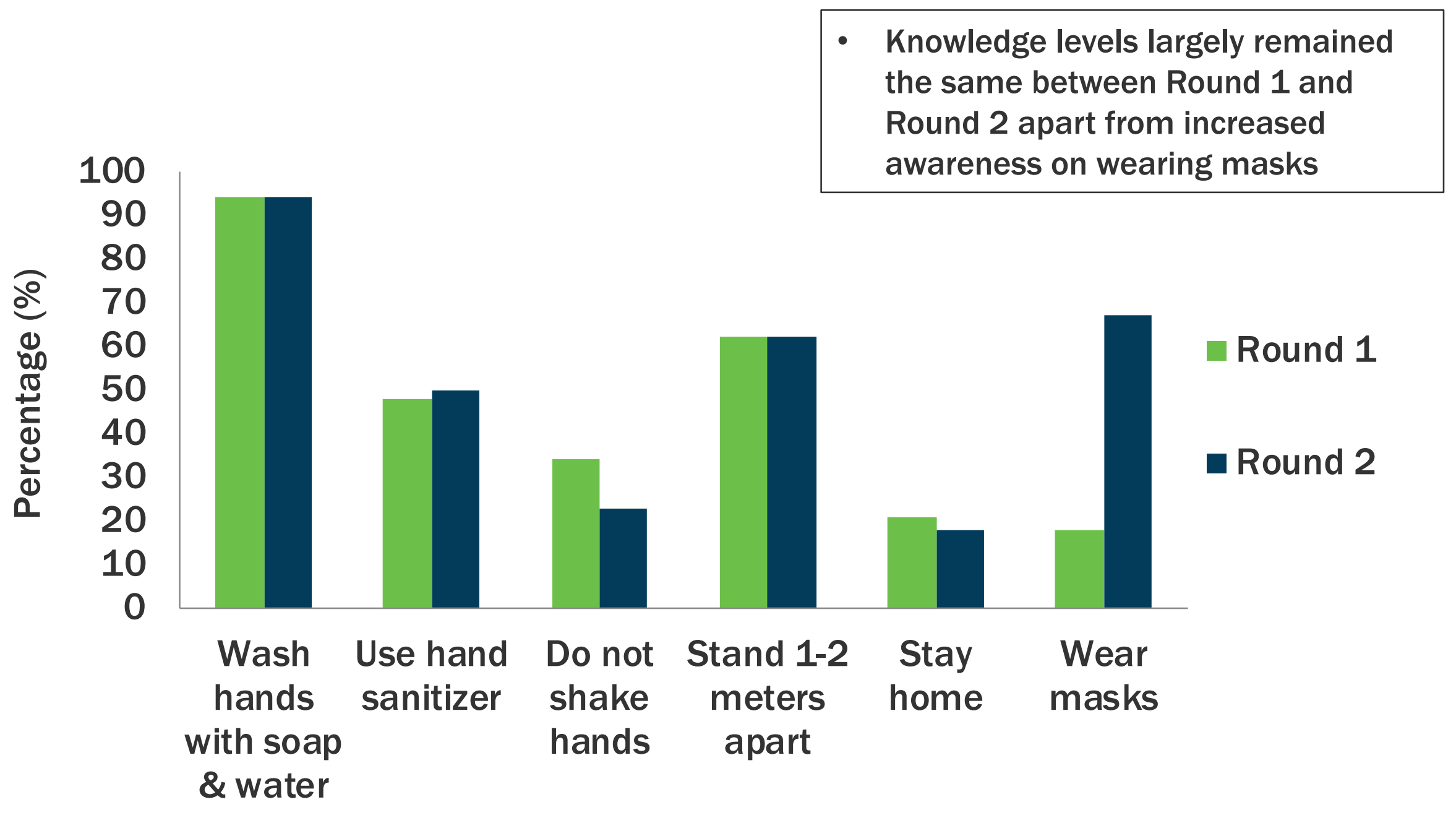




\section{Sources of Information on Coronavirus}

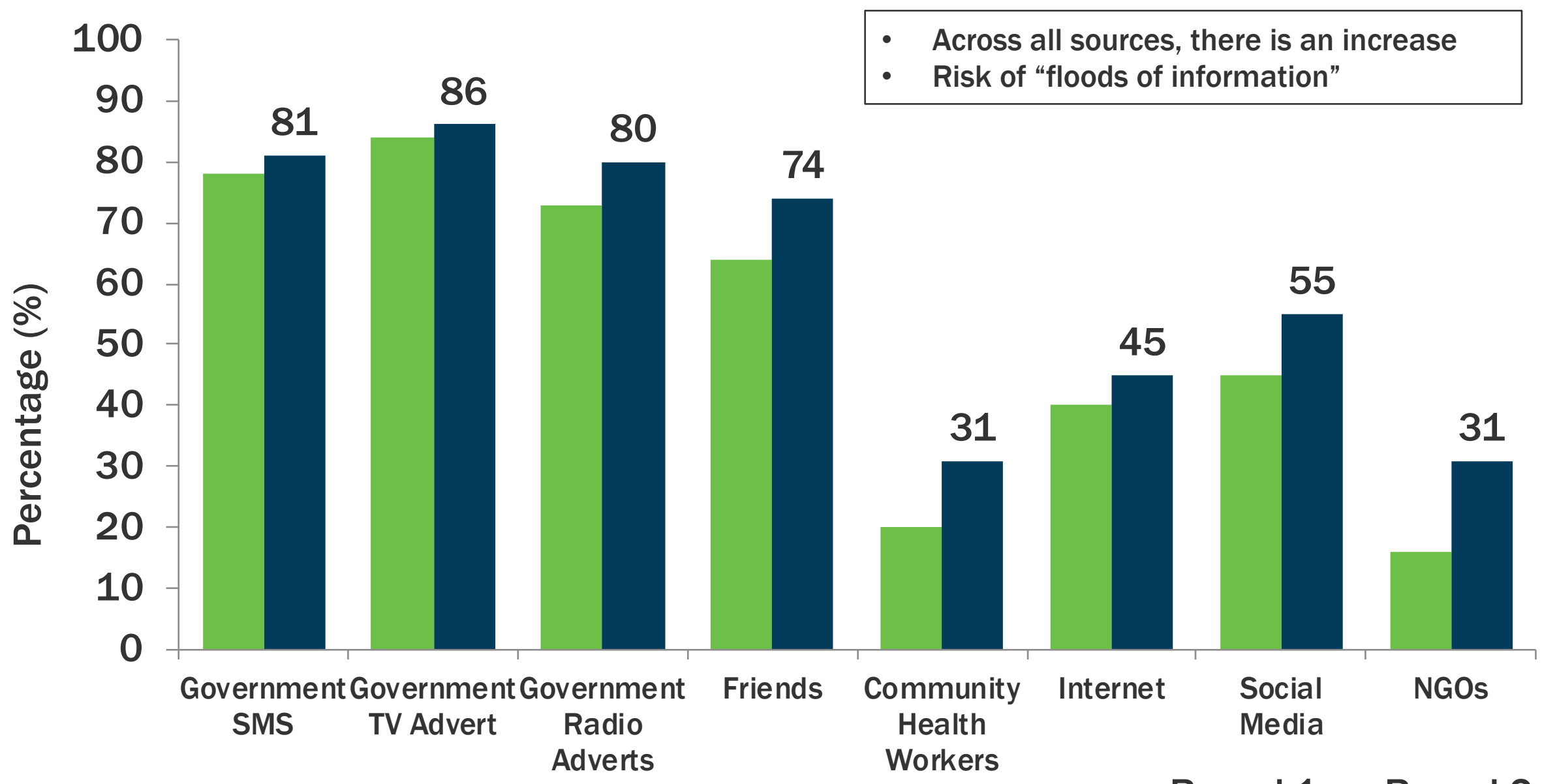

- Round 1 Round 2

*Government, NGOs and health facility/worker sources are the most trusted (>90\%) 


\section{What is your risk of being infected?}

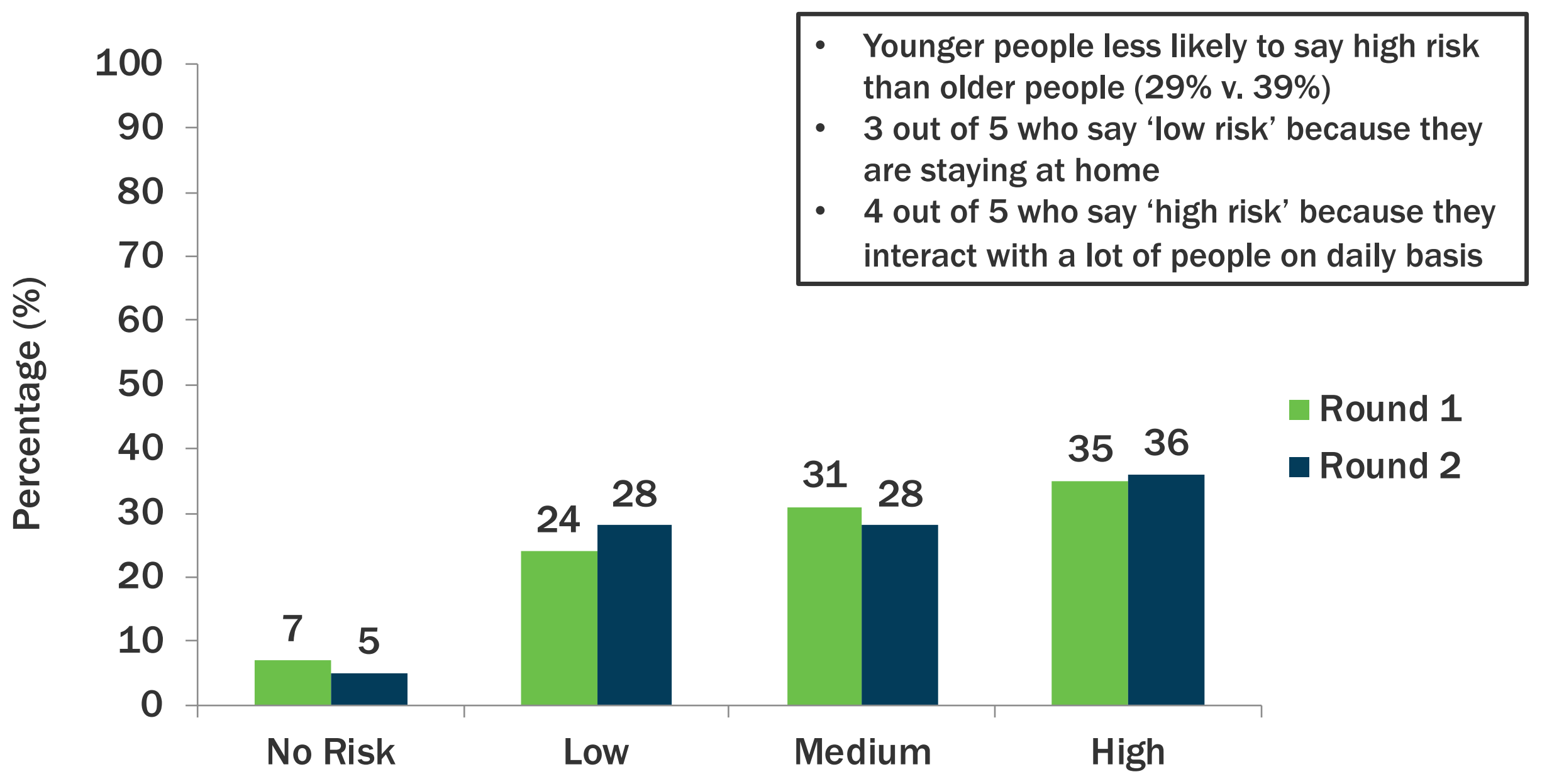




\section{If you had symptoms of COVID-19, what would you do?}

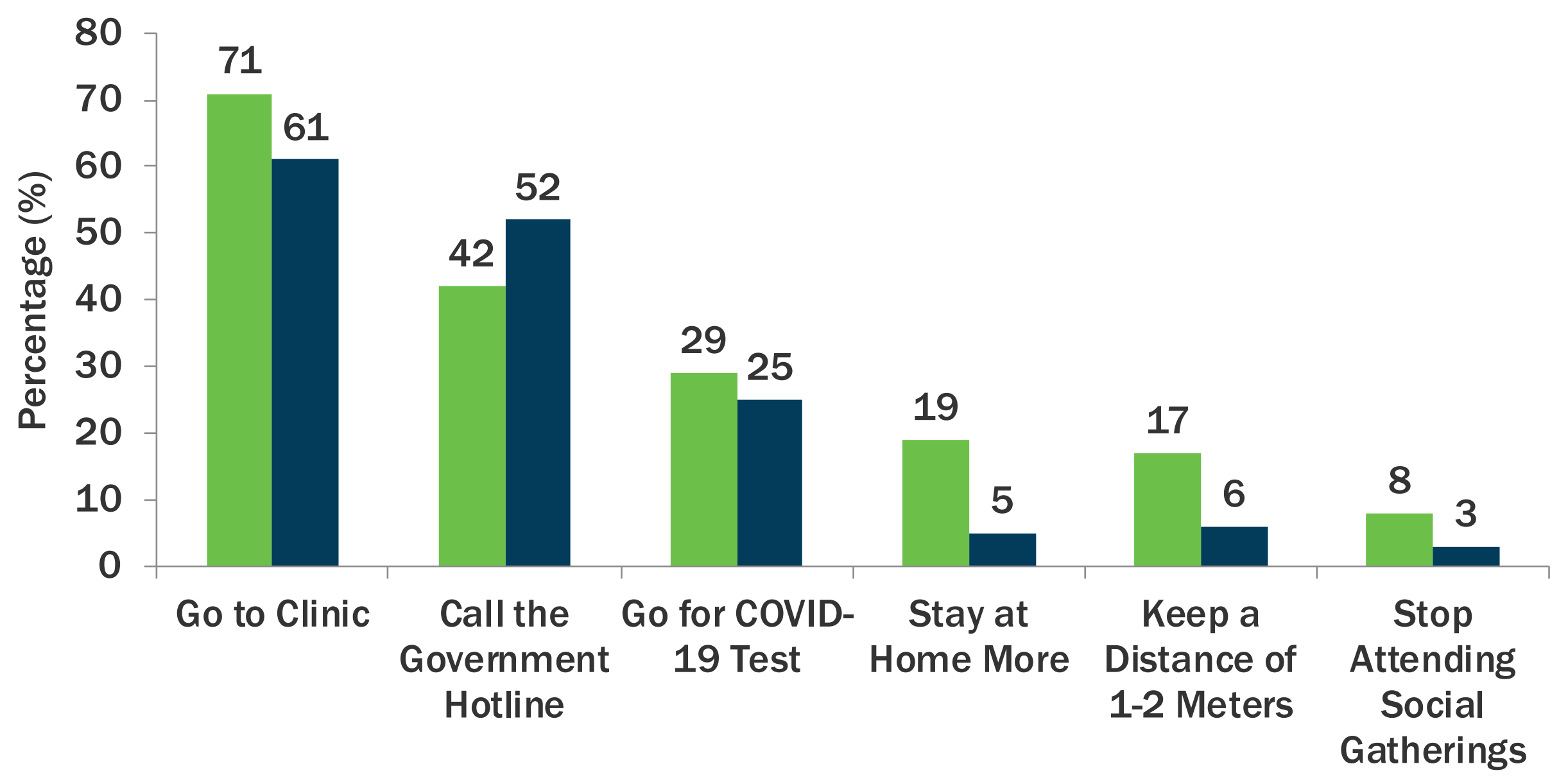




\section{Barriers to hand washing}

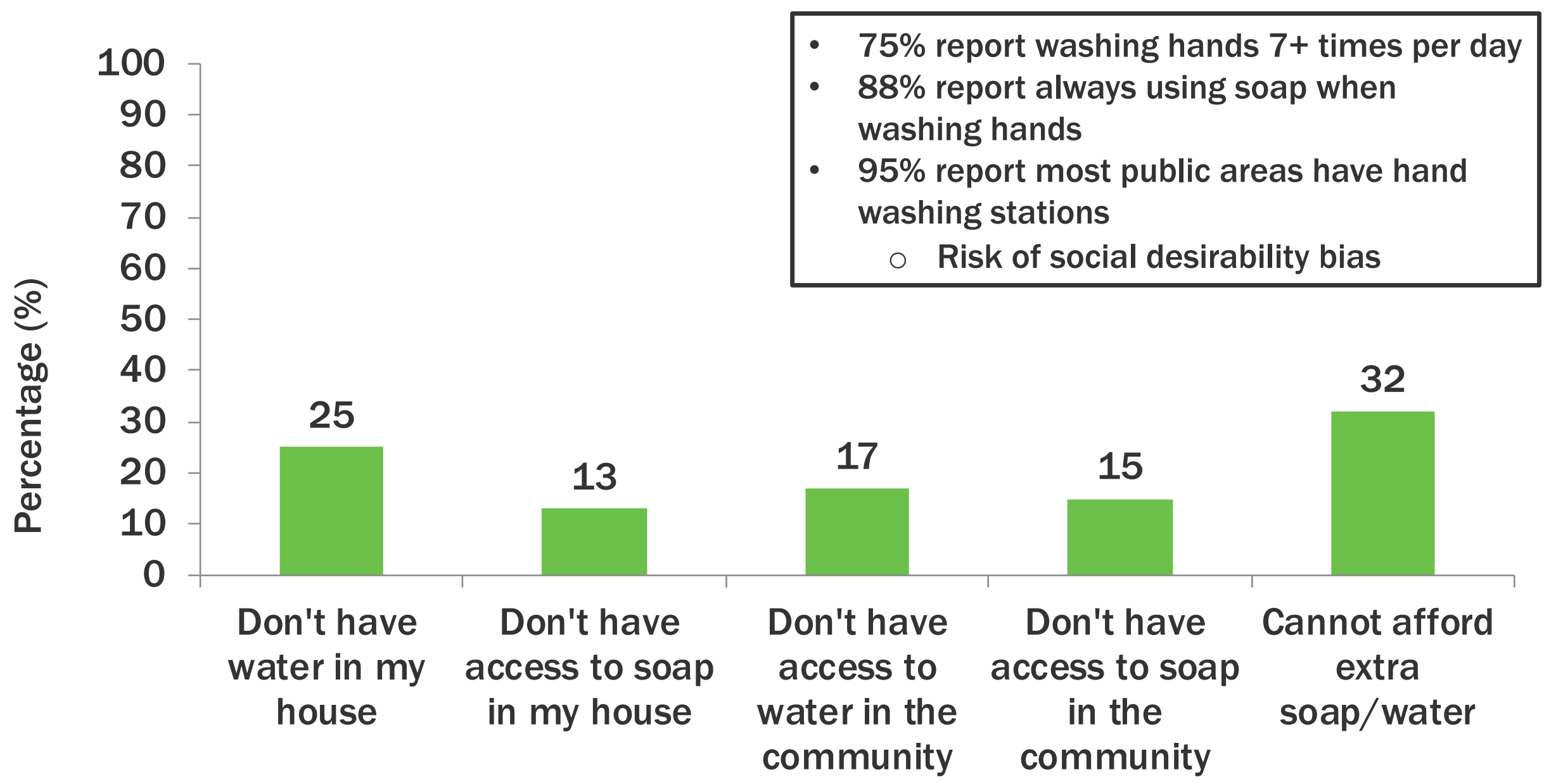




\section{Barriers to use of hand sanitizer}

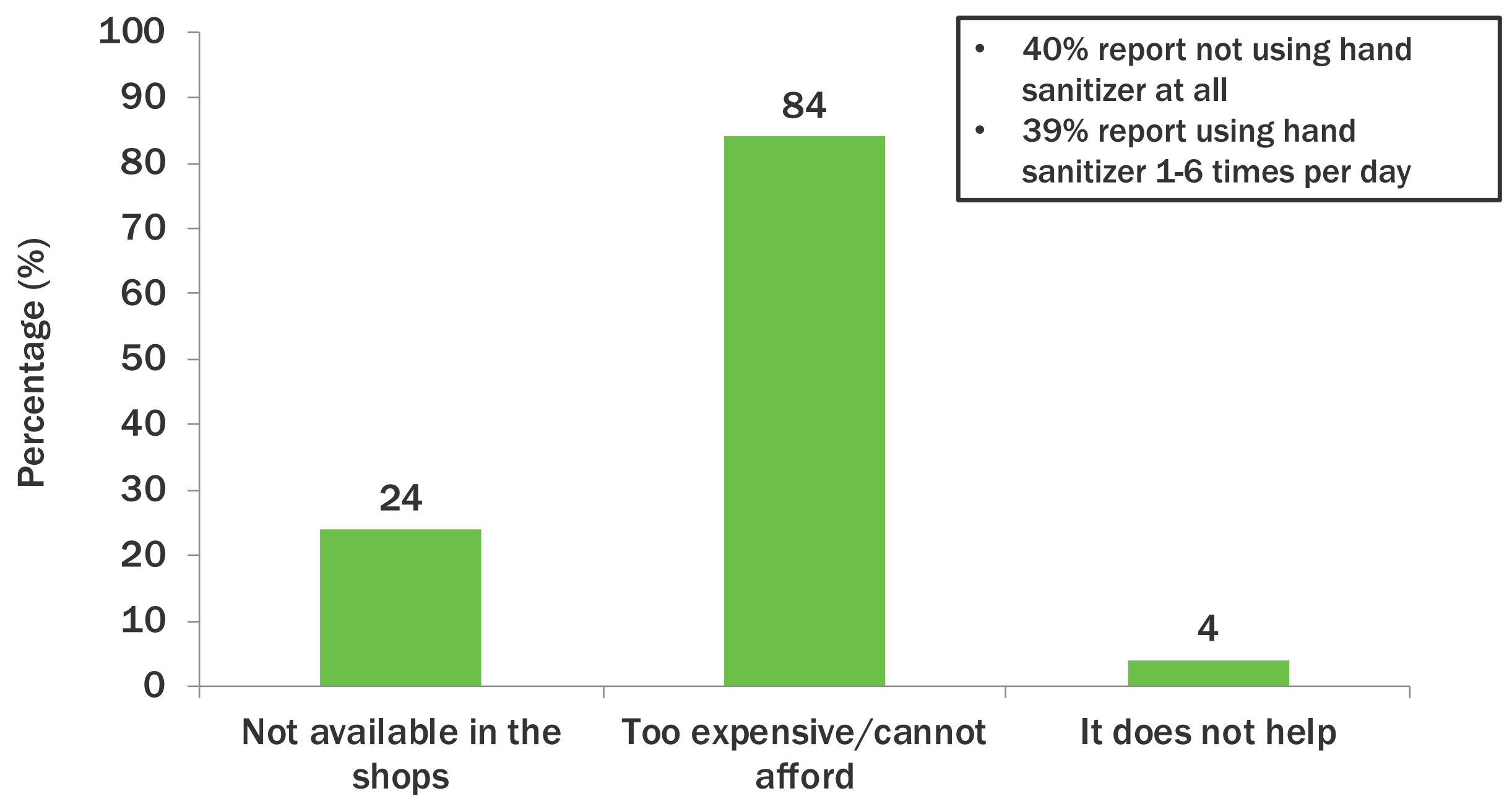




\section{Use of Face Masks}

- $73 \%$ report always wearing a mask when outside their house

$-24 \%$ report sometimes

- Common barriers

- $57 \%$ report they are uncomfortable

- 19\% report they cannot afford face masks

负 High likelihood of social desirability bias due to recent government decree on use of face masks in public 


\section{Food Security}

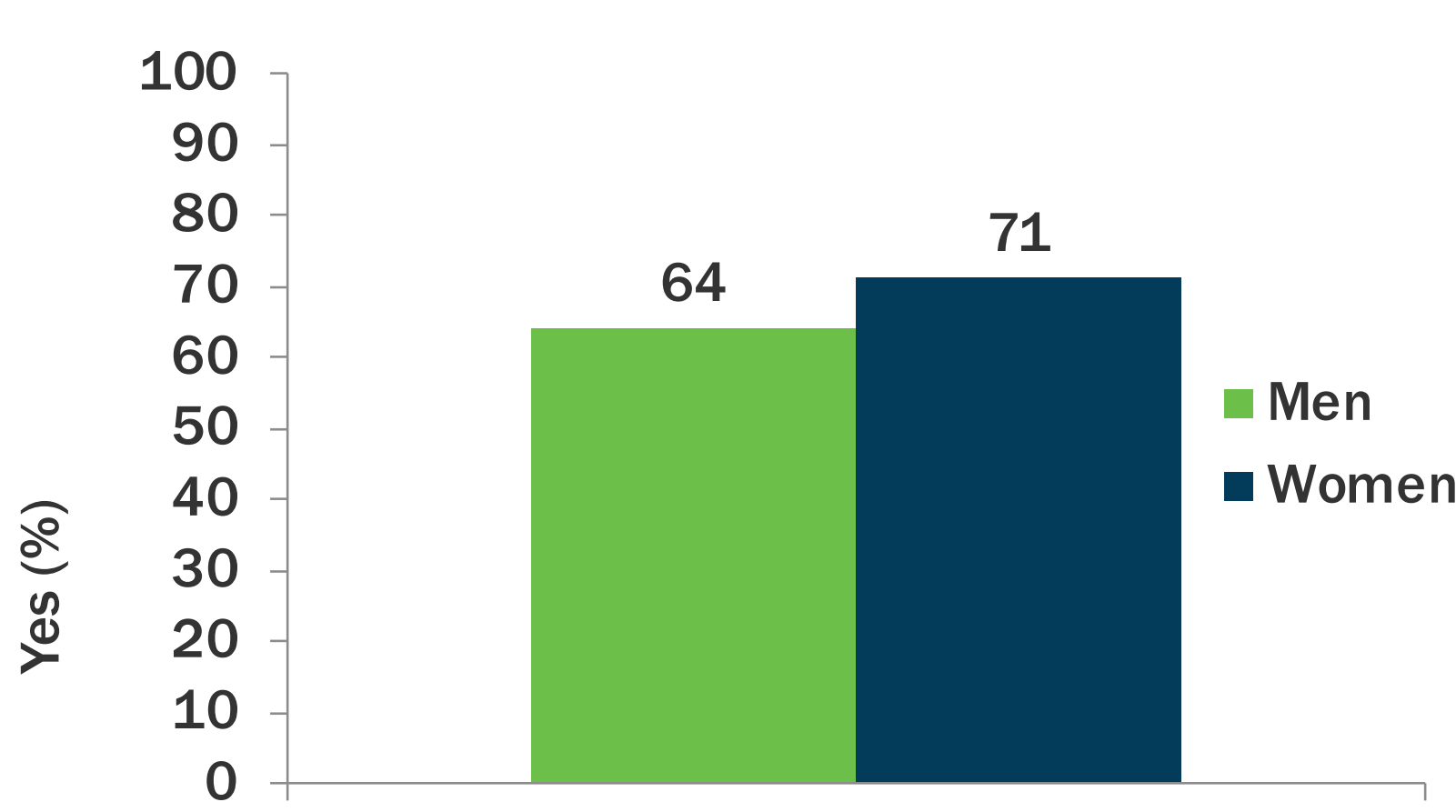

- $98 \%$ report that this is due to COVID-19

- $70 \%$ report that others in community are skipping meals/eating less due to COVID-19

Skipped meals in past two weeks?

- $76 \%$ report that their biggest need currently NOT being addressed is food 


\section{Social Effects of COVID-19}

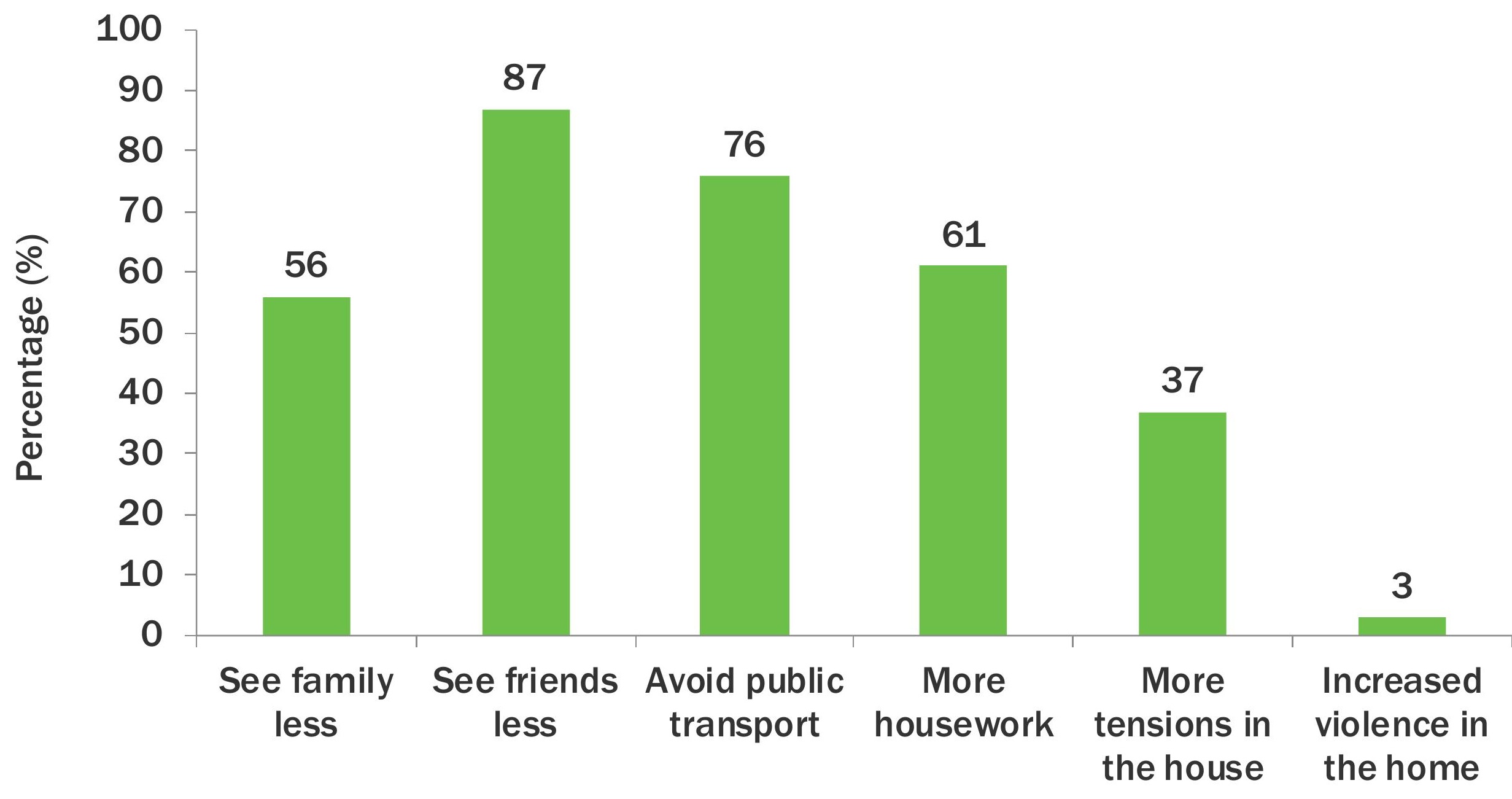




\section{Economic Effects of COVID-19}

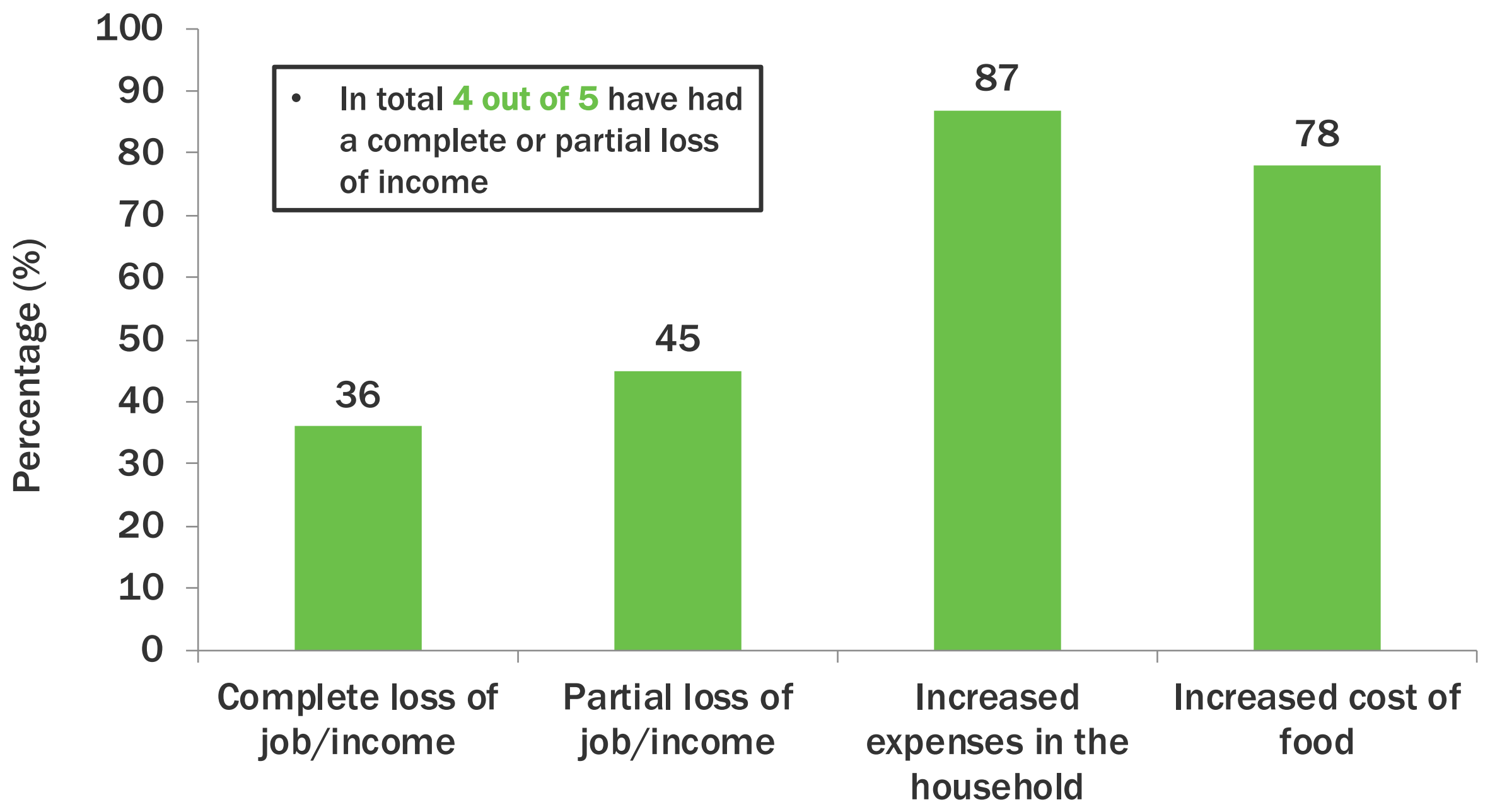




\section{Health Effects of COVID-19}

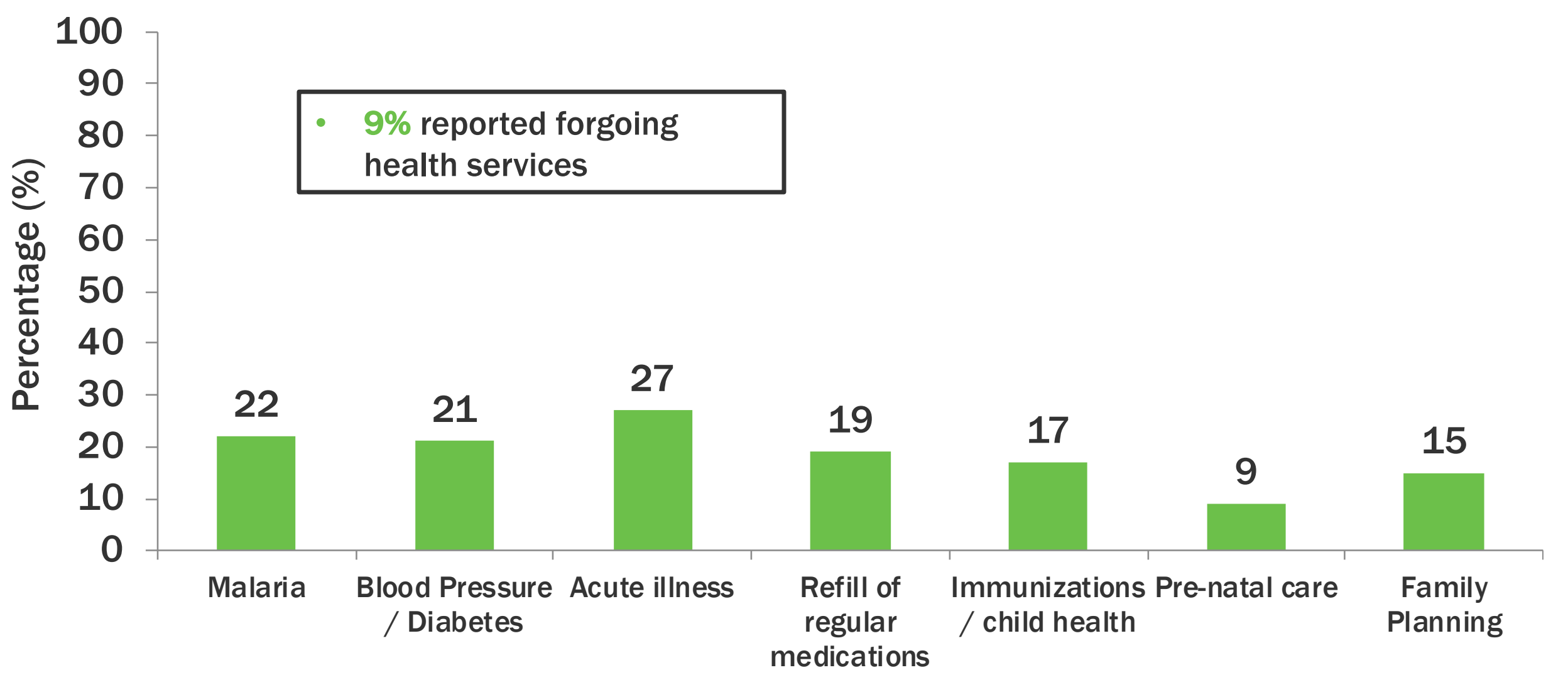




\section{Receiving Assistance?}

- Only $7 \%$ reported receiving assistance

- Of those that received:

- 72\% - soap/hand sanitizer

$-40 \%$ food

- 39\% from Good Samaritans/corporate donations

- 37\% from NGOs

- 35\% from Government

负 Those who received assistance were not those who were most likely to report losing income or missing meals 


\section{Gender Considerations}

- Women are impacted more on many of the social, health and economic dimensions. Compared to men they are more likely to have:

- completely lost their income (38\% v. 33\%)

- increased housework (67\% v. 51\%)

- increased tension in the home (39\% v. 32\%)

- forgone health care services (11\% v. 5\%)

- skipped meals due to COVID-19 (71\% v. 64\%).

- They also have less accurate knowledge of transmission, symptoms and preventive behaviors and are less likely to wear masks outside the home. 


\section{Recommendations:}

\section{Public Education Campaigns}

1) Maintain clear messages on symptoms

2) Clarify that all can be infected and pass on the virus to others - even if asymptomatic

3) People are being flooded with information from multiple sources $\rightarrow$ re-focus on prevention methods and how to access social protection 


\section{Recommendations - Social Protection}

1. Address the impacts of income loss and food security, with special attention to women

2. Ensure that those most at need of assistance are the ones receiving

a) Consider ensuring that assistance is getting into the hands of women given their increased experience of social and economic impacts 


\section{Team Members}

- Abuya, Timothy

- Austrian, Karen

- Chebet, Faith

- Isaac, Adan

- Josiah, Margaret

- Kangwana, Beth

- Mbushi, Faith

- Muluve, Eva

- Mwanga, Daniel
- Ngo, Thoai D.

- Nzioki, Mercy

- Ochako, Rhoune

- Ombeva, Joyce

- Orengo, Edwick

- Pinchoff, Jessie

- Tidwell, Ben

- Tse, Christina

- Wanyungu, John

- White, Corinne 
For more information contact

Karen Austrian (kaustrian@popcouncil.org) or

Timothy Abuya (tabuya@popcouncil.org)

Partnering with national health ministries and other government agencies in sub-Saharan Africa, South Asia, and Latin America, Population Council global and in-country scientists are conducting COVID-19 public health and social science research to produce relevant and timely evidence to support

policymakers in controlling the spread of coronavirus, evaluating the effectiveness of prevention and mitigation measures, and assessing longerterm health, social and economic effects of the pandemic. 